Lingua Rima: Jurnal Pendidikan Bahasa dan Sastra Indonesia

Vol. 10 No. 1 Januari 2021

http://jurnal.umt.ac.id/index.php//grm

\title{
PERANAN KELUARGA DALAM PEMEROLEHAN BAHASA ANAK DI MASA PANDEMIK COVID-19
}

\author{
Aprilia Pitaloka \\ Universitas Islam Negeri Syarif Hidayatullah Jakarta \\ aprilialoka00@gmail.com
}

\begin{abstract}
ABSTRAK
Tujuan penelitian ini yaitu mengetahui peranan keluarga dalam pemerolehan bahasa pertama anak berkaitan dengan informasi pandemik Covid-19. Metode penelitian ini menggunakan adalah metode deskriptif kualitatif. Data yang digunakan dalam penelitian ini yaitu ujaran verbal dalam berkaitan dengan informasi pandemik covid-19. Sumber data penelitian ini yaitu anak berusia 3 tahun 8 bulan. Teknik pengumpulan data yang dilakukan oleh peneliti yaitu teknik simak dan teknik catat. Teknik analisis data dalam penelitian ini yaitu menggunakan reduksi data, penyajian data, dan penarikan simpulan. Hasil penelitian yaitu subjek A mampu menyerap informasi bahasa pertama dari keluarga berkaitan dengan informasi covid-19. Informasi yang didapatkan berupa kata "masker", "corona", "sabun", "hand sanitizer", "virus", "bahaya", "PSBB", dan "salam corona". Selain itu, subjek A dapat mengekspresikan rasa kecemasan, kekhawatiran, dan kewaspadaan terhadap pandemik Covid-19, melalui ujaran yang sudah ia peroleh sebelumnya.
\end{abstract}

Kata kunci: keluarga, pemerolehan bahasa, pandemik Covid-19

\section{A. PENDAHULUAN}

Saat lahir manusia tidak mendapat bekal bahasa apapun. Namun, dalam perkembangannya, seorang bayi memulai belajar bahasa ketika masih dalam kandungan. Akan tetapi, ketika bayi tersebut lahir, ia belum diberi kemampuan untuk berbicara. Semakin tumbuh dan berkembang fisik bayi menjadi balita dan anak-anak, maka kemampuan berbicaranya akan semakin baik. Kemampuan berbicara tersebut dapat dipelajari dari keluarga dan lingkungan sekitar. Hal tersebut menunjukkan kemampuan pemerolehan bahasa pada anak. Istilah pemerolehan bahasa (language acquisition) yaitu proses penguasaan bahasa yang dilakukan oleh seorang anak secara natural saat mempelajari bahasa ibu (B1). Pemerolehan bahasa juga disebut sebagai proses kemampuan anak dalam memahami dan menghasilkan bahasa lisan maupun isyarat. Kemampuan ini melibatkan berbagai macam kemampuan linguistik, baik dari kemampuan semantik, kemampuan pragmatik dan lainnya. Pemerolahan bahasa dari keluarga disebut pemerolehan bahasa pertama, sedangkan pemerolehan bahasa kedua disebut pemerolehan bahasa kedua.

Kemudian, proses pemerolehan bahasa pada anak tak dapat terlepas dari peran lingkungan, sebagaimana anak adalah seseorang yang pandai dalam meniru. Pemerolehan bahasa kedua, anak secara tidak sadar mendapatkan bahasa tersebut akibat seringnya terjadi kontak komunikasi yang terus terulang-ulang hingga anak memperoleh bahasa tersebut dan menyimpannya dalam memorinya, dan sewaktu-waktu bahasa yang berupa potongan kataPeranan Keluarga dalam Pemerolehan Bahasa Anak di Masa Pandemik Covid-19 


\section{Lingua Rima: Jurnal Pendidikan Bahasa dan Sastra Indonesia \\ Vol. 10 No. 1 Januari 2021 \\ http://jurnal.umt.ac.id/index.php//grm}

kata akan terucap dengan sendirinya, karena proses kemampuan anak terhadap memahami dan menghasilkan bahasa. Peran lingkungan terbagi menjadi dua, yaitu peran lingkungan keluarga, dan peran lingkungan sekitar. Dengan adanya pandemik Covid-19, membuat banyak orang yang mengahabiskan waktunya di rumah bersama keluarga dalam kurun waktu yang cukup lama hingga masa transisi atau new normal. Selain itu, banyak kata-kata baru yang bermunculan pada saat situasi pandemik ini. Tujuan penelitian ini yaitu mengetahui peranan keluarga dalam pemerolehan bahasa pertama anak berkaitan dengan informasi pandemik Covid-19.

Pemerolehan bahasa merupakan proses penguasaan bahasa dalam masa anak-anak secara tidak langsung dalam lingkungan keluarga (ibu). Pemerolehan bahasa yang diartikan sebagai proses yang dilakukan oleh anak-anak mencapai sukses penguasaan yang lancar serta fasih terhadap bahasa ibu mereka atau yang sering di kenal dengan bahasa yang terbentuk dari lingkungan sekitar. Dalam hal ini pemerolehan bahasa pada anak akan membawa anak pada kelancaran dan kefasihan anak dalam berbicara (Sebayang, 2018:106). Pemerolehan bahasa pertama dipengaruhi oleh faktor internal dan eksternal. Faktor internal berkaitan dengan faktor kognitif, Language Acquisition Device (LAD) atau perangkat pemerolehan bahasa yang dimiliki anak sejak lahir, serta IQ anak. Faktor eksternal meliputi lingungan sosial anak dan kesempurnaan masukan bahasa anak yang diperoleh dalam kehidupan seharihari. Pada pemerolehan bahasa pertama dan bahasa kedua anak akan berupaya dapat mencapai kompetensi dan perfomansi bahasa (Mahajani \& Muhtar, 2019: 171). Pada masa pemerolehan bahasa anak, lebih mengarah kepada fungsi komunikasi daripada bentuk bahasa. Pemerolehan bahasa pada anak-anak mempunyai ciri-ciri berkesinambungan, merupakan suatu rangkaian kesatuan, dan dimulai dari ujaran satu kata yang sederhana hingga mencapai gabungan kata dan kalimat yang lebih rumit (Manurung, dalam Salnita, Atmazaki dan Abdurrahman 2019:138).

Istilah ini berbeda dengan pembelajaran (learning), yakni proses yang dilakukan dalam tataran yang formal (belajar di kelas dan diajar oleh seorang guru). Dengan demikian, proses dari anak yang belajar menguasai bahasa ibunya adalah pemerolehan, sedangkan proses dari orang (umumnya dewasa) yang belajar di kelas adalah pembelajaran (Dardjowidjojo dalam Arsanti, 2014:25). Teori pemerolehan bahasa berkaitan dengan behaviorisme dan mentalisme. Teori behavioristik hanya mengambil kelakuan yang dapat diamati sebagai titik tolak untuk deskripsi dan penjelasannya, sedangkan teori mentalistik mengambil struktur dan cara kesadaran sebagai dasarnya(Arsanti, 2014:29-30). Teori behaviorisme digagas oleh 
bapak behaviorisme di Amerika, John B. Waston. Teori behaviorisme terfokus pada sebuah aspek perilaku kebahasaan yang dapat dicermati dan dirasakan secara langsung serta hubungan antara stimulus (rangsangan) dan reaksi (respon) pada dunia sekitarnya. Teori ini beranggapan, seluruh prilaku, yaitu respon terjadi karena adanya stimulus atau rangsangan. Seperti yang dipaparkan oleh Nuryani dan Dona Aji dalam bukunya, teori behavioristik menyederhanakan pemerolehan bahasa dengan konsep stimulus dan respon (SR). Kegiatan mengulang-ngulang stimulus dalam bentuk respon adalah hal terpenting, karena hal tersebut adalah bentuk dari cara penguatan untuk tingkah laku bahasa.

\section{B. METODE PENELITIAN}

Metode penelitian ini menggunakan adalah metode deskriptif kualitatif. Peneliti menggunakan metode ini, peneliti akan menganalisis pemerolehan bahasa yang muncul secara deskriptif dan terperinci. Data yang digunakan dalam penelitian ini yaitu ujaran verbal dalam berkaitan dengan informasi pandemik covid-19. Sumber data penelitian ini yaitu anak berusia 3 tahun 8 bulan. Teknik pengumpulan data yang dilakukan oleh peneliti yaitu teknik simak dengan cara menyimak tuturan anak, dan teknik catat dengan cara mencatat tuturan yang digunakan sebagai data penelitian. Teknik analisis data dalam penelitian ini yaitu menggunakan reduksi data dengan cara memilih data yang valid berkaitan dengan tuturan informasi covid-19 anak berusia 3 tahun 8 bulan, penyajian data dengan cara menyajikan data berkait dengan pemerolehan bahasa informasi covid-19 anak berusia 3 tahun 8 bulan, dan penarikan simpulan dengan menarik simpulan dalam data yang sudah disajikan.

\section{PEMBAHASAN}

Subjek yang diteliti adalah anak berusia 3 tahun 8 bulan, bernama A, yang tingggal bersama keluarganya di Bogor. Anak tersebut berbicara menggunakan bahasa Indonesia sebagai bahasa pertama atau bahasa ibu, sebagaimana keluarganya menggunakan bahasa tersebut ketibang penggunaan bahasa daerah Sunda. Sejak kecil ia sangat pandai menirukan bahasa-bahasa yang digunakan oleh orang tuanya, neneknya, maupun kakaknya yang hanya terpaut jarak usia 4 tahun. Selama masa Pandemik, "A" tidak diizinkan oleh orang tuanya untuk keluar rumah sama sekali. Bahkan hingga saat ini, sudah berada di masa transisi atau new normal, Alisha tidak diizinkan untuk mengunjungin tempat-tempat yang mendatangkan orang banyak dan juga bermain bersama temannya di lingkungan rumahnya. Walau "A" masih berusia 3 tahun 8 bulan, orang tuanya, nenek, dan kakaknya tak melupakan untuk memberikan edukasi seputar Covid-19 secara perlahan akan tetapi secara terus-menerus. 


\section{Lingua Rima: Jurnal Pendidikan Bahasa dan Sastra Indonesia \\ Vol. 10 No. 1 Januari 2021 \\ http://jurnal.umt.ac.id/index.php/lgrm}

Pada penelitian ini data didapatkan dari hasil pertanyaan-pertanyaan yang diajukan oleh peneliti beserta keluarganya yang ikut membantu dalam mengajukan pertanyaanpertanyaan yang sudah disiapkan oleh peneliti. Informasi bahasa yang berkaitan dengan Covid-19 yang diperoleh oleh "A" sangatlah baik, hal ini tak lepas dari pengaruh keluarganya yang terus mengingatkan "A" akan Covid-19. Anak tersebut mampu memberikan respon sesuai dengan harapan.

\section{Data Pertama}

Peneliti $\quad$ : Alisha, ini masker atau bukan? (menujukan masker medis)

A : iya, itu masker, kaya Mama

Peneliti : Oh, kaya yang Mama ya. Masker buat apa?

A : Buat tutup mulut sama hidung.

Ibu A $\quad$ : Mulut sama hidungnya kenapa harus ditutup?

A : Biar gak kena corona.

Berdasarkan data pertama, subjek mampu mengetahui makna dari benda yang ditunjukan peneliti, dengan menjawab bahwa masker yang ditunjukan sama dengan masker yang selalu dipakai oleh Ibu. Subjek mampu menyerap informasi melalui lingukan sekitarnya dengan cara memperhatikan dan membandingkan. Selain itu, subjek mampu menunjukan bahasa secara fungsional, dalam semantik yaitu kegunaan masker dan situasi kondisi pada saat itu sangat berkaitan. Subjek mampu menunjukkan bahwa masker digunakan untuk pencegahan virus corona atau Covid-19. Kaitan dengan pragmatik, subjek mampu merespon pertanyaan yang diajukan peneliti secara baik.

\section{Data Kedua}

$\begin{array}{ll}\text { Peneliti } & \text { : Alisha sama mama gak boleh main ya? } \\ \text { A } & \text { : Iya gak boleh main ke luar. } \\ \text { Peneliti } & \text { : Kenapa gak boleh main ke luar rumah? } \\ \text { A } & \text { : lagi PSBB } \\ \text { Peneliti } & \text { : PSBB itu apa? } \\ \text { A } & \text { : kata Papa, Ade diem di rumah. }\end{array}$

Berdasarkan data kedua. Subjek menerima informasi mengenai PSBB, akronim dari Pembatasan Sosial Bersekala Besar. Berkaitan dengan semantik, subjek memaknai bahwa PSBB yaitu beraktivitas di dalam rumah dan tidak diperbolehkan keluar rumah. Hal tersebut berkaitan dengan subjek yang mendapatkan informasi tersebut dari Bapak.

\section{Data Ketiga}

$\begin{array}{ll}\text { Ibu A } & : \text { Ade, kalau udah pegang barang, harus apa? } \\ \text { A } & : \text { Cuci tangan } \\ \text { Peneliti } & : \text { Cuci tanganya pake apa? } \\ \text { A } & : \text { Pake sabun } \\ \text { Peneliti } & \text { : Selain pake sabun, bisa pake apa? } \\ \text { A } & \text { : han saniter (salah satu merk hand sanitizer), biar corona takut. }\end{array}$




\title{
Lingua Rima: Jurnal Pendidikan Bahasa dan Sastra Indonesia \\ Vol. 10 No. 1 Januari 2021 \\ http://jurnal.umt.ac.id/index.php//grm
}

\section{Peneliti : Kata siapa itu?}

A : Papa.

Dari data ketiga, respon dapat membedakan sabun dengan hand sanitizer dengan cepat.

Kedua kata tersebut berada dalam kesamaan semantik karena keduanya menyatakan makna 'pembersih tangan' namun dengan teknik yang berbeda. Apabila sabun harus dibilas air, sedangkan hand sanitizer tanpa bilasan air. Kebiasaan untuk mencuci tangan setelah memegang barang seperti telpon genggam, mainan, dan lainnya menjadi kebiasaan yang dilakukan oleh subjek atas dasar respon dari ketanggapannya terhadap virus Corona.

\section{Data keempat}

\author{
Kakak $A \quad$ : Ade, kalau salam gimana? \\ A $\quad:$ (mengangkant kedua telapak tanganya yang menempel) salam \\ corona. \\ Peneliti : Oh, ini salam corona? (mengikuti gerakan A) \\ A : Iya. Gak boleh deket-deket nanti ada virus, ade gak mau temenan \\ sama virus \\ Peneliti : kalau pelukan boleh? \\ A : kata mama ade, gak boleh.
}

Dari data keempat di atas, respon subjek sangat cepat dengan gerakan. Subjek memberikan contoh cara salam yang benar dengan mengangkat kedua tanganya yang saling menempel dan menaruhnya di depan wajah. Cara bersalama tersebut dilakukan tanpa sentuhan yang terjadi dengan orang lain. Hal ini juga merupakan standar yang diterapkan untuk pencegahan Covid-19. Berkaitan dengan semantic, respon yang diberikan subjek salam tersebut dinamakan 'salam corona' yaitu salam yang digunakan di saat situasi pandemik agar tidak adanya kontak langsung dengan orang-orang. Berkaitan dengan pragmatik, respon subjek yang mengetahui situasi pendemi yang harus dicegah dan diwaspadai.

\section{Data kelima}
Peneliti
: Tadi kakak disuruh ganti baju, kenapa?
A
: Di luar bahaya.
Peneliti
: Jadi harus langsung ganti baju?
A
: Biar coronanya gak ikut masuk, kan ade takut.

Dari data kelima, respon subjek yang memerintahkan peneliti untuk langsung mengganti bajunya. Subjek mengetahui situasi pandemik yang membuat dia cemas pada lingkungan sekitar. Akan tetapi, subjek subjek tidak memperlihatkan ketakutan yang berlebihan. Subjek hanya mengekspresikan rasa takutnya dengan tutur kata.

Data-data di atas, informasi diperoleh berupa kata-kata yang berkaitan dengan pandemik Covid-19 dari kalimat yang diujarkan oleh subjek. Kata-kata tersebut, yaitu masker, corona, sabun, saniter (merk hand sanitizer ), virus, bahaya, PSBB, salam corona. Selain itu, subjek sering kali meyebutkan orang tuanya yang berarti sumber informasi dari 
Lingua Rima: Jurnal Pendidikan Bahasa dan Sastra Indonesia

Vol. 10 No. 1 Januari 2021

http://jurnal.umt.ac.id/index.php//grm

orang tuanya.Kalimat tersebut merupakan respon dari mana ia mendapatkan kata-kata baru tersebut. Hal ini menandakan, pemerolehan bahasa pada anak terjadi karena adanya pengaruh dari lingkungan di sekelilingnya, terutama lingkungan keluarga yang sangat berpengaruh besar terhadap pemerolehan bahasa anak, karen sejatinya keluarga adalah dunia pertama bagi anak sejak anak lahir. Maka, di sini subjek termasuk ke dalam golongan sifat nurture dalam pemerolehan bahasa ibu.

Penelitian ini, anggapan dasar dari hipotesis tabularasa dengan teori behaviorisme. Teori ini menganggap bahwa pemerolehan bahasa pada anak dipengaruhi oleh faktor-faktor yang berada di luar, seperti lingkungan keluarga, lingkungan sekitar, budaya, dan lainnya telah terbukti kebenarannya. Pemerolehan bahasa anak terutama dalam pemerolehan bahasa ibu berasal dari pengalaman-pengalaman dari lingkungan terutama lingkungan keluarga yang didapat anak melalui S-R seperti yang ada dalam teori behaviorisme.

\section{KESIMPULAN}

Penelitian di atas telah membuktikan bahwa hipotesis tabularasa dalam teori behaviorisme terbukti melalui hasil penelitian yang dikalukan peneliti terhadap subjek A yang dapat menyerap informasi mengenai pandemik Covid-19 dari lingkungan keluarganya. Informasi yang didapatkan berupa kata "masker", "corona”, "sabun", "hand sanitizer", "virus", "bahaya", "PSBB”, dan "salam corona". Selain itu, subjek A dapat mengekspresikan rasa kecemasan, kekhawatiran, dan kewaspadaan terhadap pandemik Covid-19, melalui ujaran yang sudah ia peroleh sebelumnya.

\section{E. DAFTAR PUSTAKA}

Arsanti, M. 2014. Pemerolehan Bahasa pada Anak (Kajian Psikolinguistik). Jurnal PBSI. Vol 3 No 2 PP 24-47

Mahajani, T., Muhtar, R.H., 2019. Pemerolehan Bahasa dan Penggunaan Bahasa Anak Usia Sekolah Dasar. Jurnal Pendidikan Ilmiah Vol 5 No 3 PP 170-178

Salnita, Y. E., Atmazaki, \& Abdurrahman. 2019. Pemerolehan Bahasa pada Anak Usia 3 Tahun. Junral Obsesi. Vol 3 No 1 PP 137-145

Sebayang, S. K. H., 2018. Analisis Pemerolehan Bahasa Pertama (Bahasa Melayu) pada Anak Usia 3 Tahun. Jurnal Pena Indonesia. Vol 4 No 1 PP 105-114 